\title{
The Modern Prophet
}

Rashīd Rị̣ā's Construction of Muhammad as Religious and Social Reformer

\author{
Florian Zemmin
}

\subsection{Religious Responses to the Questions of Modern Society: The Prophets as Social Reformers}

"To my knowledge no attempt has been made in earlier times to survey the social content of the prophetical sermons and to demonstrate it in a special presentation. It is only in recent times that interest has been taken in this subject."1 Thus wrote the German Catholic theologian Franz Walter in 19oo. At the turn to the twentieth century, interest in the social teachings of prophets was indeed paramount. This is not surprising, since discursive traditions are always actualised in view of contemporary demands; and the Islamic discursive tradition is no exception here.

Under this angle, it is fruitful and enlightening to contextualise the subject matter of this chapter, namely, a modernist view of the Prophet Muhammad, within non-Islamic responses to questions of modernity. This is of course not the sole possibility to contextualise the subject at hand. The very context of the volume that this chapter is privileged to be part of manifests an equally adequate alternative, namely, to contextualise the modernist view of the Prophet dealt with here within other Islamic views of the Prophet. It should be clear that both options are not mutually exclusive, but rather complementary, and that it is indeed a matter of focus and emphasis whether one primarily highlights commonalities and differences within one discursive tradition, as this volume does, or whether one foregrounds common conditions underlying different discursive traditions, as this chapter does.

Consequently, I shall begin by recalling the centrality of social questions in modernity, which prompted the systematic search for societal principles also in religious sources. The following section introduces the journal al-Manār, the mouthpiece of Islamic modernism, at the very core of whose programme was the construction of Islam as comprising religious and social reform. This went along with constructing the Prophet Muhammad as the ideal religious and

1 Walter, Die Propheten, viii.

(C) FLORIAN ZEMMIN, 2022 | DOI:10.1163/9789004466753_015

This is an open access chapter distributed under the terms of the CC BY-NC-ND 4.q license. Zemmin - 9789004466753 
social reformer, as becomes especially clear from an analysis of a major work by the editor of al-Manār, Rashīd Riḍā, namely, his tremendously popular book al-Wahy al-muhammadī from 1933. One reason for this popularity, I suggest, was that the emotionally charged figure of the Prophet and his great appeal within his community helped Riḍa to breach his modernist understanding of Islam to a wider audience. The conclusion will then return to the relation between different discursive traditions and common paradigms and epistemic conditions, elaborating in which sense modernity is primary in Riḍā's modernist view of the Prophet.

Now, a central characteristic of modernity is its demanding answers to the question of how society ought to be organised. Secularist actors grounded their answers to this question in human nature and society alone. Spokespersons of religious traditions shared in many secular premises and views, ${ }^{2}$ but additionally grounded human nature and society in something beyond, in God. Typically, religious teachings for society were posited as superior due to them allegedly providing a firm moral foundation and also due to their alleged universal saliency. From a secular perspective, the social teachings of the prophets are a decidedly modern construction, largely in reaction to a secular position. From the perspective of a believer, in turn, these teachings, whilst of recent interest, had always been there, and it is the secularists who only now arrived at similar insights.

Thus, for example, Georg Stibitz concluded his programmatic article on "The Old Testament Prophets as Social Reformers" published in 1898 by maintaining:

If we now ask what remedy the prophets suggest for social evils, we find the answer to be a true and living faith in God which works by love toward one's fellow-man.... We have then here writers as early as eight hundred to a thousand years before Christ unanimously demanding as the purifying and plastic power of society the true and unselfish devotion of man to the supreme God, first; and, second, to his fellow-man - a position which has but recently been arrived at by a more or less pronounced evolutional and scientific method, as the conclusion of Mr. Benjamin Kidd in his Social Evolution. ${ }^{3}$

2 "Secular" in a base sense refers to this-worldly aspects, whereas "secularist" is an explicit, mostly politically relevant position that wants to grant increasing primacy or even exclusivity to this-worldly aspects.

3 Stibitz, "The Old Testament Prophets", 28. 
And five years earlier, Charles Kent in his article on "The Social Philosophy of the Royal Prophet Isaiah" had argued that by name alone "social science" is "the contribution of modern thought", but that the ancient prophets had well addressed the problem of society before, and even in a superior, non-partisan manner. ${ }^{4}$

Rather than positing either a religious or a secularist perspective on society as primary or even superior, I argue that we should view both as articulations and evaluations of a common modern condition. Since this chapter is concerned with the perspective of a religious actor in modernity, it is important to bear in mind that, from an analytical perspective, this religious actor shares in and includes fundamental secular premises, arguments, and also aims.

In order to address the questions of modern society, spokespersons of religious traditions resorted to the foundational sources of their traditions, be it the Bible, the Torah, or the Qurān, sharing in what has been called a Protestantisation of religion, alluding to Luther's credo sola scriptura. This trend became so widespread that by 1916 William Bizzell, at the time president of the Agricultural and Mechanical College of Texas, observed: ${ }^{5}$

We are in the midst of a renaissance in the study of the Old Testament scriptures. The evidence of this fact is to be found in the large number of volumes that are now appearing from the press, dealing with many phases of Jewish literature.... The content of the prophetic literature is rich in suggestiveness and social teaching for an age like our own. The realization of this fact makes it desirable to search out and evaluate this social content. This point of view has given a new significance to the work of the Jewish prophet, and stimulated a new interest in his message to the world. ${ }^{6}$

As in this example, interest in the social teachings of the prophets unsurprisingly often went hand in hand with an interest in and a reconstruction of the personae of the prophets themselves, who were said to not only have brought but also implemented these teachings in an exemplary way.

4 Kent, "The Social Philosophy", 248.

5 Additional examples of the eminent interest in the social teachings of prophets from the second decade of the twentieth century include: Breasted, "The Earliest Social Prophet"; Herrmann, Die soziale Predigt der Propheten; Rauschenbusch, The Social Principles of Jesus.

6 Bizzell, The Social Teachings, [i] (no page numbers given; this is the first page of the preface). 
This was also the case in the intellectual trend of Islamic modernism, whose very programme was to appropriate and reconstruct the Islamic discursive tradition to address the questions of modern society.

\section{2 al-Manār as an Islamic Response to the Questions of Modern Society}

The journal al-Manār, which was published from Cairo between 1898 and 1940, is widely acclaimed as the mouthpiece of Islamic modernism, that intellectual trend which aimed at formulating modernity from within the Islamic discursive tradition. Al-Manār was founded and edited by Muhammad Rashīd Ridā (1865-1935), with the help of his mentor Muhammad 'Abduh, the towering figure of modern Islamic thought (1849-1905). The basic aim of al-Manār to relate religion and society is succinctly expressed in the most famous subtitle of the journal: "a monthly journal investigating the philosophy of religion and the affairs of society and civilisation" (majalla shahriyya tabhath fi falsafat al-dīn wa-shu'ün al-ijtimā' wa-l-'umrān). ${ }^{7}$ The Islamic modernists of al-Manār wanted to reform religion from the perspective of societal requirements and at the same time wanted to reform society from a religious perspective. Both the religious and the societal perspective were validated as Islamic; and through the integration of both perspectives in an Islamic discourse, the Islamic modernists transformed Islam into a modern societal religion.

The call for both religious and social reform (al-iṣlāh al-dīni wa-l-ijtimāi $\bar{\imath}$ ) is omnipresent in al-Manār. The social either refers to worldly, secular affairs in a broad sense or it is further distinguished into the societal, the political, the economic, and the military. As is well known, Rashīd Riḍa increasingly stressed a political dimension of Islam, especially after the First World War. The possibility to construct Islam as a comprehensive programme of reform hinged on distinguishing a true universal Islam (al-islām al-dīn̄i) from its actual inner-worldly manifestations (al-islām al-dunyaw $\bar{\imath}) .{ }^{8}$ This distinction fuels Riḍā's criticism of contemporary Muslim practices, including the veneration of the Prophet, as we shall see below. Riḍa depicted himself as a reformer, a muslih, ${ }^{9}$ who wanted to educate his fellow Muslims to detach themselves

7 On the changing subtitles of al-Manār, see Zemmin, Modernity in Islamic Tradition, $146 \mathrm{ff}$.

8 For this conceptual pair, see Zemmin, Modernity in Islamic Tradition, 168ff., 404.

9 Most extensively, if implicitly so, in his fictional dialogue between "the traditionalist and the reformist", published first as a series of articles in al-Manār and then as a book (Riḍā, Kitāb muḥ̄̄warāt al-muṣlị̣ wa-l-muqallid). 
from contingent worldly practices and, as pious, educated, and critical individuals implement the universal reform programme of true Islam. Under this overarching aim, the Prophet Muhammad was not primarily to be revered as a person, but rather as the first and exemplary muṣlih, who implemented the reform programme of Islam in a most perfect manner.

This chapter argues that Riḍa constructed the figure of the Prophet to represent an ideal religious and social reformer. While firmly defending the godly truth of Muhammad's message and also God's support of his actions, Riḍā stressed Muhammad's - divinely inspired and religiously grounded - attention to inner-worldly matters. Muḥammad thus also became a role model for Riḍā himself, who proclaimed that the ideal modern society ought to be built on the foundation of the true religion, Islam. Certainly, Riḍa stresses that Muhammad was a most noble and exceptional person, which was also why God chose him to be His last prophet. However, in principle, every Muslim is able, if properly educated, to implement the reform programme of Islam, and it is in this regard that already-educated reformists, like Ridā himself, but also the 'ulamā' and rulers do have a special responsibility.

Part of the Islamic reform programme even has to be elaborated by Muslims today, who cannot merely implement Muhammad's reforming measures in wholesale detail: Riḍā, like basically all Islamic modernists, distinguishes between clear and timeless religious obligations brought by Muhammad, which must not be altered, and contingent worldly affairs for which the Quràn laid down basic principles. The latter were implemented by Muhammad in the most perfect manner in his time, but might have to manifest themselves differently in the present. Which aspects are considered to be firm obligations and which are subjected to contemporary elaboration is up for debate, and may shift over time. For example, equating the modern concept of democracy with the Qurānic concept of shürā may either lead to validating secular politics or to elaborating an Islamic political system. Riḍa most famously elaborated the political dimension of Islam in his book on the Islamic caliphate. ${ }^{10}$ Written in 1922, and thus after he had shifted his focus to the Arab world as the aspired centre of Muslim political power, Riḍā stressed Qurayshī descent as a necessary requirement of the caliph. ${ }^{11}$ It is important to recall that Riḍa retained the distinction between religion and secular politics in his modernised conception

10 Riḍā, al-Khilāfa aw al-imāma al-'użmā.

11 In this, Riḍā differed not only from non-Arab visions of the caliphate (see e.g. Willis, "Debating the Caliphate"), but also from his earlier support for an Ottoman caliph (e.g. Riḍā, “al-Khilāfa wa-l-khulafā’ (1)”). 
of the caliphate, ${ }^{12}$ and that, moreover, the Islamic politics advocated by Ridā, as well as the role of the Prophet in this regard, have to be viewed in the context of his overall programme of Islamic reform.

To this end, I will now turn to Riḍās programmatic and highly influential work al-Wahy al-muhammadī (The Revelation of Muhammad), which was first published in $1933 .^{13}$

\section{3 al-Wahy al-Muhammadī: The Prophet as Religious and Social Reformer}

"If Rị̣ā had written nothing other than al-Wahy al-muhammadī, this would have sufficed for him meriting eternal fame."14 Thus wrote Muhammad Luqmān in his eulogy on Riḍā, who had passed away in 1935. While such appraisals are generally to be taken with caution, Luqmān did and still does have a point: al-Wahy al-muhammadī indeed was a tremendous success, both immediately after its first publication in 1933 and on the longer run. A second, revised edition was issued in 1934 by the press of al-Manār ${ }^{15}$ and a third, again revised edition in $1935 \cdot{ }^{16}$ Still more impressive is the number of reviews and appraisals of the book. Ridā, who on one occasion mentions some calling his book a godly inspiration (ilhām ilāhì), ${ }^{17}$ showed no false humility in this regard. He published dozens of appraisals or reviews, ranging from a few lines to several pages, ${ }^{18}$ and also discussed the book extensively in al-Manār. ${ }^{19}$ According to

12 This is still often overlooked, even though it has been pointed out repeatedly, for example: Kerr, Islamic Reform, esp. 157, 210; Tauber, “Three Approaches, One Idea”, esp. 19o, 197ff.; Tayob, Religion in Modern Islamic Discourse, 111.

13 Rị̣ā, al-Wahy al-muhammadī.

14 Luqmān, "Muṣāb al-muslimīn", 232.

15 For the introduction and selected parts of that edition, see Rị̣ā, "Fātiḥat al-ṭab'a al-thāniya"; for a presentation of that second edition, Rị̣ā, "Taṣdīr kitāb al-wahy al-muhammadī: al-Ṭab'a al-thāniya".

16 Presented in Rị̣ā, "Kitāb al-wahy al-muhammadī: Taṣdīr al-țab‘a al-thālitha".

17 Rị̣ā, "Manār al-mujallad al-khāmis wa-l-thalāthīn", 796.

18 A large selection of reviews was collected in the book's third edition (Riḍā, al-Wahy al-muhammadī: Thubüt al-nubuwwa, 15-57). Several of the shorter reviews and appraisals included there, but also additional ones, had previously been published in al-Manār, for example: Rị̣ā, "Taqārīz kitāb al-wahy al-muhammadī"; Rị̣ā, "Kalimat fī l-wahy al-muhammad ’’; Rị̣ā, "Kitāb al-wahy al-muhammadī [collection of reviews]". For more extensive reviews, see Nābulusī, "Taqrīz"; Arslān, "Taqrīẓ”; Harāwī, "Kitāb al-wahy al-muhammadï.

19 For a critical discussion in conciliatory spirit, to which Riḍā had invited a friend of his, see Bin Yābus, "Taqrīẓ"; Riḍā, "Intiqād mas’alat al-riqq"; Riḍā, "Kashf baqiyyat al-'ālim 
Riḍā, al-Wahy al-muhammadī was also taught at the Dār al-'Ulūm, by order of the Egyptian Ministry of Education, and at some schools in Damascus and Beirut. ${ }^{20}$ Also already in 1935, Riḍa mentions a translation into Urdu and two into Chinese. ${ }^{21}$ What is certain is that a Persian translation appeared in 1939 and a Chinese one in $1946 .^{22}$ The book was also twice translated into English, once in 1958 (republished in 1960) and once in 1996. ${ }^{23}$ Both English translations are of appreciative, non-academic nature. In Arabic, there are at least eight re-editions after the Second World War. I have used the third edition from 1935 as republished in Beirut in $1985^{24}$

The popularity of al-Wahy al-muhammadī was primarily due to Riḍa showing the salience of the Prophet and of Islam in modernity, as the bulk of reviews testify to. While Ridā’s depiction of the Prophet's personality and life also continues earlier tropes, ${ }^{25}$ its relevance indeed lies in his construction of Muhammad as a modern prophet and, as I argue, as the exemplary religious and social reformer.

In the introduction to the book, which was also published as a separate article in al-Manār, ${ }^{26}$ Riḍā addresses both Europeans and those Muslims who have allegedly forgotten true Islam, ${ }^{27}$ when he states the overarching aim of the book as showing that the Qurān contains everything that humans need concerning religious, social, political, economic, and military reform ( $\mathrm{min}$

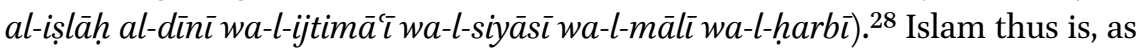

al-najdī". For an extensive polemical response of Riḍā to criticism by a Jesuit, see Riḍā, "Tafnīd i'tirāḍ kātib Jizwītī". In an antagonist debate between Riḍa and Farīd Wajdī, al-Wah̆y al-muhammadī was also a topic: Riḍā, "al-Maṭbūāt al-munkira fī l-dīn", 523-28. Riḍā, "Kitāb al-wahy al-muhammadī: Taṣdīr al-țab‘a al-thālitha", 34.

21 Riḍā, "Kitāb al-wahy al-muḥammadī: Taṣdīr al-țab'a al-thālitha", 33.

22 Rị̣ā, Vaḥi-yi Muḥammadī, and Riḍā, [al-Waḥy al-muhammadī], respectively.

23 Rị̣ā, The Revelation to Muhammad, and Rị̣ā, The Muhammadan Revelation, respectively.

24 Riḍā, al-Wahy al-muhammadī: Thubūt al-nubuwwa.

25 For some additional aspects, see Seferta, "The Prophethood".

26 Riḍā, "Muqaddimat kitāb al-wahy al-muhammadì".

27 Shakīb Arslān, the famous Arab nationalist residing in Switzerland and Rị̣ā's friend, even saw Rị̣a addressing Europeans only, since Muslims already knew what was presented in this book (Riḍā, al-Wahy al-muhammadī: Thubūt al-nubuwwa, 5o). Riḍā objected to this, saying that most Muslims in fact did not know (57); but he still directly addressed the book to Europeans in several instances, not least with the subtitle of the third edition. Riḍa also extensively responded to a Jesuit's critique of al-Wahy al-muhammadì that had been published in the Beirutian Catholic journal al-Mashriq (Rị̣ā, "Tafnīd i'tirāẹ kātib Jizwīti” ). He had also engaged Orientalists' and Christians' views on Islam and the Prophet already earlier, adducing them as strong proof for the supposed truth of Islam, whenever they shared his views; see, for example, Riḍā, "Kitāb Marjīliyūs"; Riḍā, "al-Qurān wa-najāh da'wat al-nabī”; Riḍā, "Shahādāt min 'ulamā’ al-Gharb”; see also Ryad, Islamic Reformism. 
we have said, a comprehensive programme of reform; and belief in the revelation of Muhammad is the only cure for the deadly spiritual and social poisons (al-sumūm al-rūhiyya wa-l-ijtimā'iyya al-qätila) that threaten the world today. ${ }^{29}$ Ridā lists ten goals of the Qurān, which nicely illustrate the supposed causal chain from belief in God via individual morals to social and political order.

The starting point and anchor of Ridâ’'s comprehensive reform programme is belief in God, in judgement and the hereafter, and in good deeds. Establishing this belief, is, according to Riḍā, the first goal of the Qurān. The second goal is to explain the nature and function of prophethood. Here, Riḍa stresses that the prophets were mere human beings, chosen to reveal God's mercy upon humankind and not to be revered themselves. Thirdly, the Qurān aims at the perfection of humans as individuals and collectivities; to this end, Muhammad explained that Islam is "the natural religion (din al-fitra), the religion of reason and thought (al-'aqlwa-l-fikr), of knowledge and wisdom (al-ilmwa-l-hikma), of evidence and proof (al-burhān wa-l-hujja), of the inner being and conscience (al-damìr wa-l-wijdān), and of freedom and independence (al-hurriyya wa-l-istiqla $l$ )". ${ }^{30}$ The fourth goal consists of creating unity on various levels and to thereby effect human, social, political, and national reform (al-iṣläḥ al-insānī

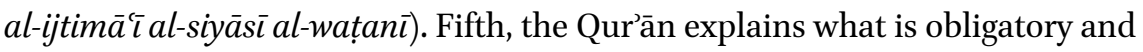
what is forbidden for humans. Most of this conforms to public interest and reason, Riḍa maintains. It is in the sphere of religious practices ( $i b \bar{a} d \bar{a} t)$ that the Prophet Muhammad has to be imitated, without any variation. The sixth goal is to explain Islamic government and politics. Goals seven to ten show how Riḍā expands from belief in God to a comprehensive programme of reform: he names as goals of the Qurān economic reform, deliverance from the dangers of war, the liberation of women, and the abolishment of slavery.

Looking more closely at the political dimension of the Islamic religion, this is needed, Riḍā argues, because religious, societal, and legal affairs can only be reformed when there is a just, that is, according to him, an Islamic, government. To this end, the Qur'ann established the following basic principles: the people are the source of power, consultation is needed, and the caliph ought to be the ruler. Muhammad was again the first to implement this reform, which is needed also in this age. Clearly, Rị̣a criticises contemporary forms of government, when he claims that

29 Rị̣ā, al-Wahy al-muhammadī: Thubūt al-nubuwwa, 92.

30 Rị̣ā, al-Wahyyal-muḥammadī: Thubūt al-nubuwwa, 257. 
the rule of the people (sultat al-umma) as the basic principle (al-qāida al-asāsiyya) of the Islamic state (dawlat al-isläm) is the greatest political reform ( $a^{\prime}$ zam iṣlāh siyāsī) brought about by the Qur'ān, in an age when all peoples of the earth were oppressed by governments in their religious and worldly affairs. The first to put this principle into practice was the Prophet of God. In order to serve as an example to those who would come after him, the Prophet never decided a matter of importance to the people without first consulting the people or its representatives. After the Prophet, the rightly guided caliphs did the same. ${ }^{31}$

The Prophet thus is not to be revered as a person, but to be esteemed as having exemplarily implemented the universally valid and rational principles of Islam - this holds true for politics as well as for the other social spheres.

It is under this aim that Rị̣a very much stresses that Muhammad was a mere human being. The argument as such is not novel, but is known from at least two contexts, one being Muslim polemics against alleged contradictions of the Christian doctrine of Jesus being both human and godly, the other being venerations of the marvellous and unrivalled language of the Qur'ân (i i jiāz), going along with stress on Muhammad allegedly having been illiterate. The emphasis Riḍā places on this aspect is, however, remarkable: al-Wahy al-muhammadī in fact originated from Riḍā's comment on Q 10:2, ${ }^{32}$ which reads: "Have the people been amazed that We revealed [the Qur'ān] to a man from among them?" More importantly, Ridā elaborates the argument that Muhammad was a mere human being under the modern paradigm of rationality: he seeks to prove this argument rationally and subsequently adduces it as proof of the rationality of Islam. Rị̣ā explicitly writes against European psychological explanations of Muhammad's revelation as mere personal inspiration. ${ }^{33}$ His own arguments are rational, scientific, and historical, Rị̣ā maintains. Thus, he asserts that psychologists, sociologists, and historians have proven that no human being can attain new knowledge through their own efforts after the age of thirty-five. Muhammad was forty years old when he received the first revelations, and he was caught by surprise himself. Ridā, then, elaborates the classical argument that Muhammad was a mere human being, as proof for the rationality and saliency of Islamic teachings and principles.

31 Riḍā, al-Wahyy al-muhammadī: Thubūt al-nubuwwa, 289.

32 Riḍā, al-Wahy al-muhammadī: Thubūt al-nubuwwa, 69.

33 In his critical assessment of Muhammad Ḥusayn Haykal's biography of the Prophet, published in 1935 (Haykal, Hayāt Muhammad), Rị̣ā even says to have written al-Wahy al-muhammadì to counter psychological explanations, and criticises Haykal for referring to such explanations (Riḍā, "Kitāb hayāt Muḥammad"). 
In line with this, Riḍā names rationality and independence of mind as major character traits of Muhammad himself, which, in combination with his elevated morals, qualified him as God's last Prophet. All prophets were free of sin, so they could serve as moral and ethical examples, Ridā maintains. ${ }^{34}$ And Muhammad was the most noble human being - he was, as Orientalists have testified to according to Riḍa, "of sound nature (salīm al-fițra) and perfect intellect (kāmil al-'aql), had noble morals (karīm al-akhlāq), was truthful (șädiq), modest ('afíf al-nafs), satisfied with little (qunüan bi-l-qalïl min $a l-r i z q)$, and was not striving for wealth or power (ghayr tamū' bi-l-māl wa-lā junūh ilā l-mulk)".35 Importantly, when Riḍā adduces the Prophet's character, he does so not in order to venerate the Prophet as such, but rather to underline the supposed principles of Islam, as becomes especially clear from the following sequence: God prepared Muhammad for his prophethood by "creating him with a perfect nature (kämil al-fitra), so that He may send him with the natural religion (din al-fitra), and He created him with a perfectly independent material intellect (kämil al-'aql al-istiqlälì al-hayūlānì), so that He may send him with the religion of independent reason and of scientific perception (din al-'aql al-mustaqill wa-l-nazar al-ilmì), and He perfected him with noble morals (kammalahu bi-ma'âli al-akhlāq) so that He may send him as the one who completes all noble traits of character (mutammiman li-makārim al-akhlāq)". ${ }^{36}$

Overall, then, while Riḍa clearly esteemed the personality of the Prophet, this in a sense was merely instrumental for his real concern of showing the truth and applicability of more abstract, universal Islamic principles. In fact, as I shall now argue, while Riḍā had long been critical of popular venerations of the Prophet, he himself resorted to the emotionally charged figure of the Prophet in order to illustrate and mediate his rationalist conception of Islam.

\subsection{Emotions and Rationality: The Prophet as Needed Exemplifier of Islamic Principles}

In the introduction to the second edition of al-Wahy al-muhammadī, Riḍa claims to have been saying the same thing for thirty years, namely, that everything that Muslims need for their reform (ișlāh) can be derived from the Qur'ān and the practice of the Prophet and his rightly guided successors. However,

34 Riḍā, al-Wahyy al-muhammadī: Thubūt al-nubuwwa, $87 \mathrm{ff}$.

35 Rị̣ā, al-Wahy al-muhammadī: Thubūt al-nubuwwa, 116.

36 Rị̣ā, al-Wahyy al-muhammadī: Thubūt al-nubuwwwa, 159. 
only few people had reacted to his call before the publication of al-Wahy al-muhammadī, which was such a tremendous success. ${ }^{37}$

To verify Riḍâs claim to consistency, one may point to a series of thirtynine lessons on God, prophethood, religion, and society that he published between 1899 and $1903 .{ }^{38}$ In the lesson on "Muhammad, the messenger of God and the seal of the prophets", the view of prophets as reformers is already well formulated: Riḍā considers also Jesus to have been a reformer (mușlih), but only a partial one, whence the world required another reformer. ${ }^{39}$ It was upon Muhammad to bring a universally valid spiritual-societal reform (al-iṣlāh al-rūḥi al-ijtimā $\bar{\imath}),{ }^{40}$ and Riḍa thinks it proven by history that the Muhammadan reform (al-iṣlāh al-muhammadī) is a necessity for all peoples. ${ }^{41}$

For this argument, Rị̣ā refers to Muḥammad 'Abduh's famous Risālat al-tawhid, ${ }^{42}$ which was a central reference for him also beyond these thirtynine lessons. In an excerpt from this treatise, published in the first volume of al-Manār, the prophets are posited as a rational requirement of society. ${ }^{43}$ Most fundamentally, in his Risälat al-tawhìd, 'Abduh validated Islam as the one religion that is suitable for modern society because it is fully rational. He does so based on an evolutionist view, arguing that by the time of Muhammad human capacities had evolved sufficiently for God addressing humans in purely rational terms, sending a message of universal validity. This basic argument was taken up by a quite diverse range of modern Islamic intellectuals. Riḍā, for his part, ${ }^{44}$ would develop 'Abduh's basic defence of the validity and necessity of Islam for modern society into a comprehensive programme of reform, increasingly integrating a political dimension into the alleged essence of Islam. Riḍā also very consistently upheld the alleged rationality of Islam: he even terminologically defined Islam as "the religion of reason (din al- $a q l)$ ", 45 and argued that the universal principles of Islam mirror reason and human interests to the extent that also non-Muslims may understand and follow them.

37 Rị̣ā, "Tașdīr kitāb al-wahy al-muḥammadī: al-Ṭabca al-thāniya", 754 .

38 I here lack the space to list all thirty-nine articles, but shall at least state the first and the last one: Rị̣ā, "al-Dars al-awwal"; Rị̣ā, "al-Dars 39".

39 Rị̣ā, "al-Dars 36", 334.

40 Riḍā, "al-Dars 36", 335 .

41 Rị̣ā, "al-Dars 36 ", 329.

42 First published in 1897, the book saw many re-editions; for an English translation, see 'Abduh, The Theology of Unity.

43 'Abduh, "Wazīfat al-rusul".

44 While Rịāa was quite successful in depicting himself as the true heir of 'Abduh, this ought to be viewed critically; see Haddad, "Abduh et ses lecteurs".

45 Riḍā, "al-Islām dīn al-'aql". 
One can hardly overstate the centrality of the Qurān in Riḍās modernist construction of Islam as a comprehensive, rationally intelligible programme of reform. It was the Qur'ann that allegedly embodied the essence of the true, universal Islam (al-islām al-dīnì). A central contributor to al-Manār, Muhammad Tawfìq Șidqī, even programmatically exclaimed that, "Islam is the Qurān alone."46 The very fact that this claim to exclusivity was criticised also in al-Manā ${ }^{47}$ underlines the novelty of this modern, essentialist understanding of Islam, centred on scripture. To Riḍa, the Qur'ān embodied the primary essence of Islam, whereas the Prophet and his successful, pious successors in a secondary sense helped to understand the Qurānic message and showed its veracity and applicability. In other words: the Prophet and his faithful companions and successors showed the success resulting from internalising and applying the Islamic message. According to Riḍa, this could and should happen again today, whence he called Muslims to again take heed of true Islamic principles and to, as pious, active, and responsible individuals, construct a proper and successful society.

Speaking both to the centrality of the Qurān and the consistency of Riḍā's argument, it is worth pointing out that al-Wahy al-muhammadì did not only originate from the commentary on one Qurānic verse, as I had mentioned, but was in fact largely based on the Tafsìr al-manār and was initially intended as a general summary of it. ${ }^{48}$ The Tafsir al-manār was first serialised in volumes 3 to 34 of Riḍā's journal and then published as a twelve-volume book. Up to Q 4:125, it was based on lessons by 'Abduh, but should overall be considered the work of Riḍā, who edited 'Abduh's lessons and completed the commentary until Q 12. ${ }^{49}$ Expressing the programme of Islamic modernism, the Tafsìr al-manār aimed at showing the societal relevance of the Qur'àn, along with its rationality. According to Riḍa, the Qur'ān, which he considers itself to be proven rationally and scientifically, is the only miracle that can be taken as proof for the veracity of Muhammad's message. ${ }^{50}$

This argument goes hand in hand with Riḍā's longstanding criticism of belief in miracles. Riḍa of course would not deny the miracles effected by Muhammad as stated in the Qurân; but he stresses that these were godly signs against those who opposed Muhammad, and were never meant as proof to his mission. In a similar vein, Riḍā adduces the quick expansion of Islam as

\footnotetext{
46 Ṣidqī, "al-Islām huwa al-Qurān waḥdahu".

47 Bāz, "al-Dīn kull mā jāaa bi-hi al-rusul".

48 Rị̣ā, "Tașdīr kitāb al-waḥy al-muḥammadī: al-Ṭaba al-thāniya”, 753.

49 The most extensive study on the Tafsìr al-manār is Jomier, Le Commentaire.

50 Rị̣ā, al-Wahy al-muhammadī: Thubūt al-nubuwwa, 93-118, 221-56.
} 
historical proof for the godly origin of Muhammad's message. God also helped His Prophet in this regard, granting him victory and sending signs to support his prophethood, but it is the historical facts that stand as alleged scientific proof in this age of reason. Riḍâs rationalist criticism of belief in miracles in general can be seen under his overarching aim of detaching religion from unreflected beliefs and social practices, as Richard van Leeuwen showed. ${ }^{51}$

In a similar vein, Riḍā criticised other popular socio-religious practices, not least the mawālid, festivities on occasion of the birth of a prophet or saint. ${ }^{52}$ Mawālid were more widely targeted as irrational and backward in Egypt at the turn to the twentieth century. ${ }^{53}$ Riḍā very much shared in this trend, devoting a separate section to festivities (al-mawālid wa-l-mawāsim) in early volumes of al-Manāar. ${ }^{54}$ Already in 1898 , he criticised the mawälid on two lines, again pursuing his aim of reconstructing Islam as a modern, societal religion: comparing mawālid with fairs and exhibitions in Europe, Riḍa bemoaned that the mawālid are uncivilised and lack the benefits of coming together in society. ${ }^{55}$ Complementarily, he criticised certain practices, like standing up on mentioning of the Prophet's birth, as harmful innovations. ${ }^{56}$ A year later, in 1899, Ridā, who was pleased to remark that some harmful innovations had recently been prohibited, but still criticised many current practices, sketched his own vision of how the stories (qișaș) read aloud on occasion of the Prophet's birthday should look like: "The stories of the birthday of the Prophet that we hear and see all comprise what is not true (mā la yașahhh) and they are void of the most important aspect they must contain, namely, praise (tanwih) of the great reform (al-ișlăh al-'azìm) that occurred in the world through the one whose birthday we celebrate (șâhib al-mawlid). ${ }^{.57}$

Still dissatisfied with the current state of the mawlid, Riḍa in 1917 then wrote his own treatise to commemorate the birth of the Prophet. ${ }^{58}$ This treatise only contains sound hadìths and narrations, Riḍā maintains. He, however, shifts quickly from the person of Muhammad to his mission, and foregrounds the

51 van Leeuwen, "Islamic Reformism".

$5^{2}$ A related practice was the visiting of saints' shrines or tombs (van Leeuwen, "Reformist Islam").

53 Schielke, "Hegemonic Encounters".

54 Examples for articles in this section are Riḍā, "Kayfa nantafi' bi-l-mawālid wa-l-mawāsim”; Rị̣ā, "Qism al-mawālid wa-l-mawāsim".

55 Riḍā, "al-Mawālid aw al-maāâị̣".

56 Riḍā, "Munkarāt al-mawālid".

57 Riḍā, "al-Mawlid al-nabaw̄̄", 291.

$5^{8}$ The articles serialised in volume 19 of al-Manār were not fully identical with the book published later, as Riḍā mentions in the introduction (Riḍā, "Muqaddima li-dhikrā l-mawlid al-nabawī", 31). For Riḍā’s response to a critic of his treatise, see Riḍā, "Radd al-Manār". 
societal dimension of Islam. The aspired aim of the treatise is precisely what Riḍā had demanded from such stories above, namely, to remember the great reform (al-ișlāh al-'azìm) that God sent His Prophet with. "The Islamic reform (al-ișlāh al-islāmī)," he maintains, "is based on furthering the ișlăh of people through the independence of reason and will (istiqlāl al-'aql wa-l-irāada) and the purification of morals (tahdhïb al-akhlāq)."59

Marion Katz included Riḍā's treatise in her broader analysis of mawlid commemorations, concluding that: "In content, the text is a modernist biography of the Prophet that eliminates most of the supernatural and miraculous elements of the traditional story to emphasize the ethical and social progressiveness of the Prophet's mission." 60 The new style, content, and aim also showed in other reformist treatises on the mawlid in the first decades of the twentieth century: "In their determined focus on the Prophet's mission, its impact on society, and the imperative for individual believers to emulate his example, such [reformist] texts radically de-emphasized the significance of his birth." ${ }^{\prime 1}$ In a sense, Rịā and other reformists tried to rationalise the mawlid, introducing also modern notions of bounded individualism and emotional subjectivity. ${ }^{62}$

At the same time, the mawlid and the figure of the Prophet were successful means to emotionally mediate more abstract principles and teachings to a wider populace. An abridged version of Riḍā's treatise ${ }^{63}$ - which, notably, was republished in 2007 - replaced the previous story at the official celebrations in Cairo already in $1916 .{ }^{64}$ In the 193os Riḍa fulfilled ongoing demands, voiced not least from India where his previous treatise had been very popular, to produce additional texts on occasion of the mawlid. ${ }^{65}$ Thus, for the mawlid of the year 1932, he composed a treatise on the rights of women, using again the Prophet as ideal example for implementing the principles of Islam. ${ }^{66}$ And while al-Wahy al-muhammadi was not explicitly written for the mawlid, it, too, was presented on that very day, as Riḍa highlighted. ${ }^{67}$

One thus may note a certain ambivalence in Ridâ’s view on the figure of the Prophet: on the one hand, he criticised personal veneration of the Prophet

59 Rị̣ā, "Dhikrā l-mawlid al-nabawī [part 1]", 415.

6o Katz, The Birth of the Prophet Muhammad, 178.

61 Katz, The Birth of the Prophet Muhammad, 180.

62 Katz, The Birth of the Prophet Muhammad, 2ogff.

63 Rị̣ā, Mukhtașar dhikrā l-mawlid al-nabawī.

64 Riḍā, "Muqaddima li-dhikrā l-mawlid", 31.

65 Rị̣ā, "Dhikrā l-mawlid al-nabawī [part 2]".

66 Rị̣ā, "Dhikrā l-mawlid al-nabawī [part 2]", 131.

67 Riḍā, "Dhikrā l-mawlid al-nabawī [part 2]", 131; Riḍā, "Taṣdīr kitāa al-wahy al-muhammadè", 759 . 
and very much identified Muhammad with the message he brought, taking him as the exemplary reformist illustrating the success of the comprehensive programme of Islamic reform, which had to be implemented again today. On the other hand, since the Prophet remained that emotionally charged figure able to integrate his community, Ridā pushed for venerating a specific image of the Prophet, namely, his own construction of Muhammad as a religious and social reformer. This ambivalence is no contradiction, but rather results from and bespeaks of Riḍa reconstructing the Islamic discursive tradition under the conditions of modernity.

While the intersecting of classical tropes and novel views is constitutive of this process of reconstruction, in the last consequence it occurs under the primacy of modernity, as I shall suggest in my concluding remarks.

\subsection{Conclusion: Modern Religions, Modern Prophets}

This chapter was concerned with the view of the Prophet Muhammad by a most prominent and influential spokesperson of the Islamic discursive tradition in modern times, Rashīd Riḍā. While it should be clear that Riḍā does not stand in for the intellectual trend of Islamic modernism as a whole, the interest in social teachings of Islam is one of those aspects widely shared in modernity. Also the Indian, rather pro-British, and secularist modernist Sayyid Ahmad Khān, for example, added the English subtitle "The Mohammedan Social Reformer" to his journal Tahzīb ul-akhlāq. And today, a blogger may proclaim without much explanation that Muhammad was "the best social reformer". 68

Riḍā's own construction of the Prophet as a religious and social reformer was intrinsically related to his construction of Islam as a comprehensive programme of reform. He thereby provided an Islamic answer to the primary and continuous question of modernity, namely, on which basis society ought to be organised. Rị̂a argued that this basis could only be religion. For he shared in the categorical distinction between religion and the secular, but denied that the secular could be self-sufficient. Put otherwise, he complemented the modern concept of religion as belief with a modern functionalist understanding of religion as a social necessity. On this basis, Riḍā, as the editor of al-Manār, the most prominent Islamic journal (al-majalla al-islämiyya) in the Arabic public sphere, provided Islamic answers to all questions pressing in that public sphere, whether religion, economics, gender relations, or politics. After all, this 
is the role of the journalist and the public intellectual that Ridā was. ${ }^{69}$ That said, Ridā was not only a journalist, but he equally was a muṣliḥ, an Islamic reformist. As a journalist and a muṣlị̣, Rị̣ā wanted to publicly educate his fellow Muslims and citizens to become pious, moral, and rational individuals. Only thus would they be able to internalise and implement the reform programme of Islam, the veracity and success of which had allegedly been shown by the first and ideal Islamic mușlih, the Prophet Muhammad.

The fact that Ridā was both a journalist and a muṣlih illustrates the complex intersection of classical and novel aspects, of continuity and change that is constitutive of every major actualisation of a discursive tradition. An eminent asset of Talal Asad's conception of Islam as a discursive tradition ${ }^{70}$ was precisely to bring into view both commonalities and differences, both continuities and changes between the manifold articulations of Islam across time and space. The volume of which this chapter is part of very much testifies to this manifoldness. After all, the Prophet Muhammad is one central element of the Islamic discursive tradition; and it will be fascinating to see both common and differing elements in the varied views on the Prophet brought together here. Since Riḍa very consciously made sure to articulate his modernist arguments from within the Islamic discursive tradition, it follows that many of the tropes and symbols he used are known from earlier instantiations of that tradition. At the same time, Riḍa with his modernist construction of Islam was not simply updating these earlier forms in a new context. While discursive traditions represent a most plausible and insightful category of analysis, individual articulations of one tradition are often more adequately understood by looking beyond that tradition. This, I argue, is the case with Riḍa's modernist construction of the Prophet, concerning which the primacy of modernity comes to the forefront when viewing it together not with earlier articulations of the Islamic discursive tradition, but rather with contemporaneous articulations of other traditions.

As part of his general argument of Islam being the only tradition suitable for and able to sustain modernity, Rị̣ā himself would of course maintain that Muhammad was the only prophet combining social and spiritual reform. Muhammad combined and thereby surpassed the partial reforms of Moses and Jesus, as Riḍa would sometimes add. ${ }^{71}$ However, as we have seen already in the introduction, Ridā actually participated in broader intellectual trends of modernity that reconstructed religious traditions to address the questions of

69 Hamzah, "Muhammad Rashid Ridâ"; Skovgaard-Petersen, "Portrait of the Intellectual".

70 First formulated in Asad, The Idea of an Anthropology of Islam, 14-17.

71 For example, Riḍā, "al-Dars 36 ", 333 ff. 
modern society. An especially widely shared argument was that religious social teachings were superior to secular ones, because they added a firm moral foundation. Take the following argument of an English Christian theologian from 1917: "The principles which the prophets exalted as the standards of social wellbeing are as valid now as ever they were. For the social problem is not economic alone. At bottom it is moral and religious. So, after our economists have taught us all they can of the science of distribution and the laws that make for wealth and poverty, we must still turn to seers like the prophets of Israel for spiritual enlightenment and guidance, for the quickening of the sense of humanity and God. ${ }^{\prime 2}$

While basic arguments like this would, then, be elaborated differently in different discursive traditions and across differing sociopolitical contexts, they in a fundamental sense illustrate the primacy of modernity in Riḍâ's appropriation of the Islamic tradition. This is to say: while there is a diachronic continuity of symbols and references within one discursive tradition, these symbols and references are appropriated and actualised under epistemic conditions and according to paradigms common across synchronic discursive traditions. On the former level, we observe many commonalities between Riḍā and Islamic thinkers of earlier times. On the latter level, in turn, Islamic modernism shows greater similarities with Christian or even secular modernism than with premodern Islamic intellectual debates. Put otherwise: the framing of "modernist Islam" highlights commonalities within one discursive tradition, while the wording of "Islamic modernism" underlines the common conditions shaping different traditions. It is in the latter sense, foregrounded in this chapter, that modernity is primary in Ridâ’s appropriation of the Islamic tradition, including his construction of the Prophet Muhammad.

\section{Bibliography}

\section{Primary Sources}

'Abduh, M. "Wazīifat al-rusul 'alayhim al-salām (min Risālat al-tawhīd)", al-Manār 1/16 (1898), 286-94.

'Abduh, M. The Theology of Unity, trans. Ishaq Musa'ad and Kenneth Cragg, London, Allen \& Unwin, 1966.

Arslān, Sh. "Taqrīz Amīr al-Bayān Shakīb Arslān”, al-Manār 34/1 (1934), 56-63. Bāz, A. M. "al-Dīn kull mā jāa bi-hi al-rusul", al-Manār 9/8 (19o6), 610-14.

72 Gordon, “The Prophets", 283. 
Bin Yābus, 'A. b. 'A. “Taqrīẓ kitāb al-waḥy al-muḥammadī wa-intiqāduhu”, al-Manār 34/2 (1934), 140-43.

Bizzell, W. B. The Social Teachings of the Jewish Prophets: A Study in Biblical Sociology, Boston, Sherman, French \& Co, 1916.

Farooqi, S. "Prophet Muhammad: The Best Social Reformer", About Islam, 22 January 2018. Accessed 20 December 2018. http://aboutislam.net/reading-islam/about -muhammad/prophet-muhammad-the-best-social-reformer/.

Gordon, A. R. "The Prophets and the Social Question", The Biblical World 5o/5 (1917), 282-89.

Harāwī, Ḥ. "Kitāb al-waḥy al-muḥammadī: Naqd wa-taḥlīl, naẓra 'așriyya fĩ i'jāz al-Qửān", al-Manār 34/1 (1934), 64-67.

Haykal, M. Ḥ. Hayāt Muḥammad, 2nd ed., Cairo, Maṭba'at Miṣr, [1935].

Herrmann, J. Die soziale Predigt der Propheten, Berlin-Lichterfelde, Runge, 1911.

Kent, C. F. "The Social Philosophy of the Royal Prophet Isaiah", The Biblical World 1/4 (1893), 248-62.

Luqmān, M. 'A. I. "Muṣāb al-muslimīn fĩ a'ẓam 'ulamā’ihim wa-a'qal ḥukamāihim", al-Manār 35/3 (1935), 229-33.

Nābulusī, 'A. Ḥ. S. "Taqrīẓ al-ustādh al-shaykh 'Abd al-Ḥamīd al-Sā’ị̣ al-Nābulusī”, al-Manār 34/1 (1934), 53-55.

Rauschenbusch, W. The Social Principles of Jesus, New York, The Woman's Press, 1917.

Riḍā, M. R. "al-Khilāfa wa-l-khulafā' (1)", al-Manar 1/33 (1898), 628-33.

Riḍā, M. R. "al-Mawālid aw al-macāriḍ”, al-Manār 1/4 (1898), 79-87.

Riḍā, M. R. "Munkarāt al-mawālid", al-Manār 1/6 (1898), 93-101.

Rị̣ā, M. R. "al-Dars al-awwal: Tamhīd wa-muqaddimāt", al-Manār 2/26 (1899), 438-42.

Riḍā, M. R. "al-Mawlid al-nabawī al-sharīf", al-Manār 2/19 (1899), 289-91.

Riḍā, M. R. "Kayfa nantafic bi-l-mawālid wa-l-mawāsim”, 3/22 (1900), 525-28.

Riḍā, M. R. "Qism al-mawālid wa-l-mawāsim”, al-Manār 4/9 (19o1), 36o.

Rị̣ā, M. R. "al-Dars 36: Muḥammad rasūl Allāh wa-khātim al-nabiyīn”, al-Manār 5/9 (1902), 329-38.

Riḍā, M. R. "al-Dars 39 āyat Allāh al-kubrā: al-Qurān", al-Manār 6/7 (1903), 247-51.

Riụā, M. R. "al-Islām dīn al-'aql”, al-Manār 5/21 (1903), 807-18.

Riḍā, M. R. "Kitāb Marjīliyūs [Margoliouth] fī l-nabī", al-Manār 9/7 (19o6), 533-38.

Rị̣ā, M. R. Kitāb muḥāwarāt al-muṣlị̣ wa-l-muqallid wa-l-wahda al-islāmiyya, Cairo, Mațba'at al-Manār, [1907/8].

Rị̣ā, M. R. "al-Qurān wa-najāh da'wat al-nabī: Arā' 'ulamā' Ūrubā fī dhalik", al-Manār 11/1 (1908), 9-31.

Riḍā, M. R. "Dhikrā l-mawlid al-nabawī [part 1]", al-Manār 19/7 (1916), 408-25.

Rị̣ā, M. R. "Muqaddima li-dhikrā l-mawlid al-nabaw $\vec{\iota}$, al-Manār 20/1 (1917), 23-32.

Riḍā, M. R. "Radd al-Manār 'alā l-nāqid li-dhikrā l-mawlid al-nabaw $\vec{\imath}$, al-Manār 20/9 (1918), 395-403. 
Rị̣ā, M. R. al-Khilāfa aw al-imāma al-'uzmā: Mabāhith shar 'iyya siyāsiyya ïjtimāaìya iṣlāḥiyya, Cairo, Mațba'at al-Manār, 1923.

Riḍā, M. R. "Shahādāt min 'ulamā' al-Gharb al-munșifin li-l-Islām wa-l-nabī wa-lmuslimīn (1)", al-Manār 30/2 (1929), 140-44.

Riḍā, M. R. "Fātiḥat al-țab'a al-thāniya min kitāb al-wahyy al-muḥammadī [pp. 593-6o1]; Maziyyat hādhihi al-țab‘a 'alā l-ūlā [p. 6o2]; al-Fașl al-awwal [pp. 6o3-8]; 'Ișmat al-anbiyā' [pp. 6o9-14]", al-Manār 33/8 (1933), 593-614.

Riḍā, M. R. "al-Mațbū'āt al-munkira fī l-dīn wa-mashyakhat al-Azhar", al-Manār 33/6 (1933), 513-37.

Riḍā, M. R. "Muqaddimat kitāb al-wahyy al-muḥammad ̄’, al-Manār 33/4 (1933), 282-89.

Rị̣ā, M. R. al-Waḥy al-muḥammadī, Cairo, Mațba'at al-Manār, 1933.

Riḍā, M. R. "Dhikrā l-mawlid al-nabawī [part 2]”, al-Manār 34/2 (1934), 129-39.

Riḍā, M. R. "Intiqād mas’alat al-riqq wa-l-jawāb ‘anhu", al-Manār 34/2 (1934), 144-46.

Riḍā,M. R. "Kashf baqiyyatal-ālim al-najdī fì kalimātminkitābal-wahy al-muhammad al-Manār 34/3 (1934), 216-31.

Riḍā, M. R. "Tafnīd i'tirāẹ kātib Jizwìtī 'alā kitāb al-waḥy al-muhammad̄̄", al-Manār 34/2-5 (1934), 147-51, 227-31, 311-15, 376-81.

Riḍā, M. R. "Taqārīz kitāb al-wahyy al-muḥammadī", al-Manār 33/9-10 (1934), 697-710, 768-91.

Riḍā, M. R. "Taṣdīr kitāb al-waḥy al-muḥammadī: al-Ṭab‘a al-thāniya”, al-Manār 33/10 (1934), 753-59.

Riḍā, M. R. "Kalimat fì l-wahyy al-muhammad̄̄", al-Manār 34/7 (1935), 556-59.

Rị̣ā, M. R. "Kitāb ḥayāt Muḥammad (ṣ): al-Ḥukm bayna al-mukhtalifīn fỉhi", al-Manār 34/10 (1935), 787-93.

Riḍā, M. R. "Kitāb al-wahyy al-muhamamadī [collection of reviews]", al-Manār 35/1 (1935), $55^{-63 .}$

Riḍā, M. R. "Kitāb al-waḥy al-muḥammadī: Tașdīr al-țab`a al-thālitha", al-Manār 35/1 (1935), 33-40.

Rị̣ā, M. R. "Manār al-mujallad al-khāmis wa-l-thalāthīn", al-Manār 34/10 (1935), 794-99.

Rị̣ā, M. R. Vaḥīyi Muhammadi, trans. Muḥammad 'Alī Khalīlī, [Tehran,] Shirkat-ichāp-khānah-yi 'ilmī, 1939.

Rị̣ā, M. R. [al-Wahy al-muhammadī], trans. Ruitu Ma, Shanghai, Zhonghua shu ju, 1946.

Riḍā, M. R. al-Waḥy al-muḥammadī: Thubūt al-nubuwwa wa-l-Qur'ān wa-da'wat shu'ūb al-madaniyya ilā l-Islām dìn al-akhìra li-l-insāniyya wa-l-salām, 3rd ed., Beirut, Mu’assasat 'Izz al-Dīn li-l-Tibā'a wa-l-Nashr, [1985/86].

Riḍā, M. R. The Muhammadan Revelation, trans. Yusuf T. DeLorenzo, Alexandria, Al-Saadawi Publications, 1996. 
Rị̣ā, M. R. Mukhtașar dhikrā l-mawlid al-nabawī, Cairo/Minneapolis, Dār al-Nashr li-l-Jāmi'āt/Dar Almanar, 2007.

Riḍā, M. R. The Revelation to Muhammad, trans. Abdus-Samad Sharafuddin, 2nd ed., Bhiwandi [India], Ad-Darul-Qayyimah, n.d.

Șidqī, M. T. "al-Islām huwa al-Qur’ān waḥdahu”, al-Manār 9/7 (1906), 515-25.

Stibitz, G. "The Old Testament Prophets as Social Reformers", The Biblical World 12/1 (1898), 20-28.

\section{Secondary Literature}

Asad, T. The Idea of an Anthropology of Islam, Washington, DC, Centre for Contemporary Arab Studies, Georgetown University, 1986.

Breasted, J. H. "The Earliest Social Prophet: Reviewed Work: The Admonitions of an Egyptian Sage by Alan H. Gardiner", The American Journal of Theology 14/1 (1910), $114-16$.

Haddad, M. "Abduh et ses lecteurs: Pour une histoire critique des 'lectures' de M. 'Abduh", Arabica 45/1 (1997), 22-49.

Hamzah, D. "Muhammad Rashid Ridâ (1865-1935) or: The Importance of Being (a) Journalist", in H. Bock, J. Feuchter, and M. Knecht, eds, Religion and Its Other: Secular and Sacral Concepts and Practices in Interaction, Frankfurt/New York, Campus, 2008, 40-63.

Jomier, J. Le Commentaire Coranique du Manār, Paris, G.-P. Maisonneuve, 1954.

Katz, M. H. The Birth of the Prophet Muhammad: Devotional Piety in Sunni Islam, London/New York, Routledge, 2007.

Kerr, M. Islamic Reform: The Political and Legal Theories of Muhammad Abduh and Rashìd Rid̄ā, Berkeley, University of California Press, 1966.

Ryad, U. Islamic Reformism and Christianity: A Critical Reading of the Works of Muhammad Rashïd Riḍā and His Associates (1898-1935), Leiden, Brill, 2009.

Schielke, S. "Hegemonic Encounters: Criticism of Saints-Day Festivals and the Formation of Modern Islam in Late 19th- and Early 2oth-Century Egypt", Die Welt des Islams 47/3-4 (2007), 319-55.

Seferta, Y. H. R. "The Prophethood of Muhammad in the Writings of Muhammad 'Abduh and Rashid Rida", Hamdard Islamicus 8 (1985), 11-29.

Skovgaard-Petersen, J. "Portrait of the Intellectual as a Young Man: Rašīd Riḍā's Muhāwarāt al-muṣliḥ wa-al-muqallid (1906)", Christian-Muslim Relations 12/1 (2001), 93-104.

Tauber, E. "Three Approaches, One Idea: Religion and State in the Thought of 'Abd al-Rahman al-Kawakibi, Najib 'Azuri and Rashid Rida", British Journal of Middle Eastern Studies 21/2 (1994), 190-98.

Tayob, A. Religion in Modern Islamic Discourse, London, Hurst, 2009. 
van Leeuwen, R. "Islamic Reformism and the Secular: Rashid Ridâ's Theory on Miracles”, in H. Bock, J. Feuchter, and M. Knecht, eds, Religion and Its Other: Secular and Sacral Concepts and Practices in Interaction, Frankfurt/New York, Campus, 2008, 64-78.

van Leeuwen, R. "Reformist Islam and Popular Beliefs: Rashīd Riḍās Attack against the Cult of Shrines", in V. Klemm and N. al-Sha'ar, eds, Sources and Approaches across Disciplines in Near Eastern Studies: Proceedings of the 24th Congress, Union Européenne des Arabisants et Islamisants, Leipzig 2008, Leuven/Paris/Walpole, MA, Uitgeverij Peters/Departement Oosterse Studies, 2013, 141-54.

Walter, F. Die Propheten in ihrem sozialen Beruf und das Wirtschaftsleben ihrer Zeit: ein Beitr. zur Geschichte der Sozialethik, Freiburg i. Breisgau, Herder, 1900.

Willis, J. "Debating the Caliphate: Islam and Nation in the Work of Rashid Rida and Abul Kalam Azad", The International History Review 32/4 (2010), 711-32.

Zemmin, F. Modernity in Islamic Tradition: The Concept of "Society" in the Journal alManar (Cairo, 1898-1940), Berlin, De Gruyter, 2018. 